\title{
Hubungan Antara Motivasi Peternak Perempuan Dengan Keberlanjutan Usaha Peternakan Sapi Perah (Kasus Pada Peternak Perempuan Anggota KSU Karya Nugraha Kelurahan Cipari Kecamatan Cigugur Kabupaten Kuningan)
}

\author{
The Correlation Between Motivation of Female Farmer And Business \\ Sustainability of Dairy Farm (The Case of Female \\ Dairy Farmer Member of KSU Karya Nugraha Cipari \\ Sub-District, Cigugur District, Kuningan Regency)
}

\author{
Mochamad Rizqy Lutfhiana ${ }^{1}$, Ali Mauludin ${ }^{2}$, Lilis Nurlina ${ }^{2}$. \\ ${ }^{1}$ Alumni Fakultas Peternakan Universitas Padjadjaran Tahun 2019 \\ ${ }^{2}$ Staff Pengajar Fakultas Peternakan Universitas Padjadajaran \\ Email:
}

\begin{abstract}
ABSTRAK
Penelitian ini dilaksanakan pada bulan Januari 2019 pada peternak perempuan anggota KSU Karya Nugraha di Kelurahan Cipari Kecamatan Cigugur Kabupaten Kuningan Jawa Barat. Tujuan dari penelitian ini adalah untuk mengetahui motivasi peternak perempuan, keberlanjutan usaha peternakan sapi perahnya, serta untuk menganalisis hubungan antara kedua variabel tersebut. Penelitian ini dilakukan dengan pendekatan kuantitatif menggunakan metode survei. Teknik pengambilan sampel dilakukan dengan metode Proportional Random Sampling dengan jumlah sampel sebanyak 30 responden yang tersebar dari 7 kelompok. Hasil penelitian menunjukan bahwa motivasi peternak perempuan termasuk dalam kategori sedang $(60 \%)$ yang artinya motivasi peternak perempuan sudah cukup baik, keberlanjutan usaha dari peternak perempuan termasuk dalam kategori sedang $(53,33 \%)$ yang artinya peternak perempuan sudah cukup baik dalam mempertahankan usahanya, dan terdapat hubungan yang cukup kuat antara motivasi dengan keberlanjutan usaha, dengan nilai korelasi sebesar 0,472 .
\end{abstract}

Kata Kunci : Anggota Peternak Perempuan, Motivasi, Keberlanjutan usaha

\begin{abstract}
This research was held on January 2019 to female dairy farmer the member of KSU Karya Nugraha in Cipari Sub-District, Cigugur District, Kuningan Regency, West Java. The purpose of this research was to analyze the motivation of female farmers, the sustainability of their dairy farm, also to analyze the correlation between both variable. This research was held with quantitative approach used the survey method. The sampling technique used the Proportional Random Sampling method and total sample of respondents was 30 persons from 7 groups. The results of research showed that the motivation of female farmers was in the medium category (60\%) which mean the motivation of female dairy farmer was good enough, also the business sustainability of female farmers was in the medium category (53.33\%) which mean they are good enough in maintain their business, and there was a medium correlation between motivation and business sustainability, with the coefficient of correlation is 0.472 .
\end{abstract}

Keywords: Female Dairy Farmer Member, Motivation, Business Sustainability. 


\section{A. PENDAHULUAN}

Populasi sapi perah di Indonesia meningkat dari tahun ke tahun, dilihat dari data statistik Direktoral Jenderal Peternakan dan Kesehatan Hewan (2018) banyaknya populasi sapi perah pada Tahun 2016 sebanyak 533.833 ekor, Tahun 2017 sebanyak 544.781 ekor, dan Tahun 2018 sebanyak 550.000 ekor. Banyaknya produksi susu sapi perah di Indonesia Tahun 2016 sebanyak 912.735 ton, Tahun 2017 sebanyak 920.093 ton, dan Tahun 2018 sebanyak 909.600 ton.

Usaha peternakan sapi perah tersebut tidak terlepas dari peran peternak sebagai pelaku yang menjalankan usaha dan peran koperasi sebagai wadah peternak dalam menjalankan usahanya. Salah satu koperasi yang mewadahi kegiatan usaha peternak sapi perah di Kecamatan Cigugur adalah Koperasi Serba Usaha (KSU) Karya Nugraha. Peternak sapi perah yang tergabung sebagai anggota di KSU Karya Nugraha sebanyak 873 orang yang mencakup 700 orang laki-laki, dan 173 orang perempuan. Sebaran anggota perempuan berada di Kelurahan Cipari sebanyak 72 orang, Desa Cisantana sebanyak 63 orang, Desa Babakan sebanyak 20 orang, Kelurahan Cigugur sebanyak 10 orang, dan Desa Gunung Keling sebanyak 8 orang. Dilihat dari data tersebut menunjukan adanya kontribusi perempuan dalam kegiatan usaha peternakan sapi perah.

Keterlibatan peternak perempuan pada aktifitas usaha ternak sapi perah dipengaruhi oleh motivasi. Motivasi merupakan sebuah dorongan dan usaha untuk mencapai tujuan tertentu atau untuk memenuhi kebutuhannya (Arep dan Tanjung, 2003). Atas dasar tujuan dan pemenuhan kebutuhan akan menimbulkan dorongan dalam diri individu untuk melakukan pekerjaan maupun kegiatan yang akan mendukung dirinya untuk mencapai tujuan. Begitu pula dengan peternak perempuan dalam bekerja di ranah peternakan sapi perah didasarkan atas suatu tujuan.
Motivasi merupakan hal yang menimbulkan dorongan berupa aktivitas atau kegiatan melalui proses psikologis, baik yang dipengaruhi oleh faktor motivator (intrinsik) yaitu motif yang timbul dari dalam diri seseorang (latar belakang pendidikan, pengalaman, kebutuhan) maupun faktor higine (ekstrinsik) yaitu motif yang timbul akibat dorongan dari luar atau lingkungan (lingkungan kerja, rekan, kompensasi) (Hezberg, 1996 dalam Wahjosumidjo, 2000).

Mengetahui motivasi pada peternak perempuan secara tidak langsung dapat mengetahui juga keberlanjutan usaha yang dijalani oleh peternak perempuan tersebut. Keberlanjutan usaha merupakan terjemahan dari "sustainable livelihood" yang dapat didefinisikan sebagai upaya individu untuk memenuhi kebutuhan hidup dan keberlanjutan hidupnya dengan memanfaatkan segala kemampuan, akses, pengetahuan, tuntutan, serta kekayaan yang dimiliki dan terus meningkatkan kemampuan dirinya dengan bekerja sama dengan orang lain, berinovasi, agar dapat bertahan dalam berbagai perubahan kondisi (Chambers dan Conway, 1992 dalam Nurlina, 2008).

\section{B. MATERI DAN METODE}

\section{a. Subjek Penelitian}

Subjek dalam penelitian ini adalah anggota peternak perempuan di KSU Karya Nugraha Jaya yang berada di Kelurahan Cipari Kecamatan Cigugur, Kabupaten Kuningan, Provinsi Jawa Barat, dengan objek penelitian yaitu motivasi pada peternak perempuan dan keberlanjutan usaha peternakan sapi perah.

\section{c. Metode Penelitian}

Metode penelitian yang digunakan adalah survei dengan metode deskriptif. Lebih luas lagi penelitian ini menggunakan pendekatan kualitatif yang dikuantitatifkan. Maksud dari kualitatif dalam penelitian ini adalah datanya. Data kualitatif adalah data yang diwujudkan dalam 
kata keadaan atau sifat. Pada penelitian ini kata keadaan tersebut adalah motivasi dan keberlanjutan usaha. Data yang didapat dari kata keadaan tersebut berupa angka dan dimasukan ke dalam kategori kelas, maka disebut pendekatan kualitatif yang dikualitatifkan (kuantifikasi). Informasi yang diperlukan diperoleh dari responden menggunakan kuesioner yang telah dipersiapkan sebelumnya. Menurut Singarimbun dan Effendi (1987) penelitian survei merupakan penelitian yang mengambil sampel dari satu populasi menggunakan kuesioner sebagai alat pengumpul data.

Penelitian ini dilaksanakan di salah satu subwilayah kerja Koperasi Serba Usaha (KSU) Karya Nugraha yaitu Kelurahan Cipari, Kecamatan Cigugur, Kabupaten Kuningan, Provinsi Jawa Barat. Dipilihnya tempat ini sebagai tempat penelitian karena KSU Karya Nugraha merupakan koperasi yang bergerak di bidang sapi perah di Kabupaten Kuningan. Selain itu Kelurahan Cipari merupakan sub-wilayah kerja KSU Karya Nugaraha yang memiliki anggota peternak perempuan terbanyak yaitu sebanyak 72 orang.

Responden dalam penelitian ini ditentukan dengan cara "Proportional Random Sampling". Menurut Arikunto (2012) Propotional Random Sampling adalah teknik pengambilan sampel secara proporsi dengan mengambil subyek dari setiap strata atau setiap wilayah ditentukan seimbang dengan banyaknya subyek dalam masing - masing strata atau wilayah. Responden dalam penelitian ini adalah peternak sapi perah perempuan yang tergabung sebagai anggota KSU Karya Nugraha di Kelurahan Cipari Kecamatan Cigugur, Kabupaten Kuningan, Jawa Barat.

Responden diambil sebanyak 30 orang yang mewakili tujuh kelompok yang didapat dari perhitungan rumus sebagai berikut :

Keterangan :

$$
\mathrm{n}=\frac{\mathrm{X}}{\mathrm{N}} \mathrm{N}_{1}
$$

$\mathrm{n}=\underset{\text { Jumlah sampel yang diinginkan dari setiap }}{\text { kelompok }}$
$\mathrm{N}=$ Jumlah seluruh populasi peternak perempuan anggota KSU di Kelurahan Cipari

$\mathrm{X}=$ Jumlah populasi pada setiap strata populasi

$\mathrm{N}_{1}=$ Sampel

Penentuan sampel responden pada masing masing kelompok berdasarkan rumus di atas diperoleh hasil sebagai berikut :

Tabel 1. Responden Peternak Perempuan Kelurahan Cipari

\begin{tabular}{llcc}
\hline No. & $\begin{array}{l}\text { Nama } \\
\text { Kelompok }\end{array}$ & $\begin{array}{c}\text { Populasi } \\
\text { (orang) }\end{array}$ & $\begin{array}{c}\text { Sampel } \\
\text { (orang) }\end{array}$ \\
\hline 1 & Cipari 1 & 10 & 4 \\
2 & Cipari 2 & 4 & 2 \\
3 & Musium & 20 & 8 \\
4 & Kondang & & \\
& 1/MCU & 19 & 8 \\
5 & Cisumur & 9 & 4 \\
6 & Kondang 2 & 6 & 2 \\
7 & Cibulakan & 4 & 2 \\
\hline & Jumlah & 72 & 30 \\
\hline
\end{tabular}

Variabel yang digunakan dalam penelitian ini yaitu Motivasi Peternak Perempuan (Variabel X) dan Keberlanjutan Usaha (Variabel Y). Variabel Motivasi terdiri atas Motivasi Intrinsik dan Motivasi Ekstrinsik. Indikator dalam motivasi intrinsik yaitu tanggung jawab dan kesempatan maju, sedangkan indikator motivasi ekstrinsik yaitu relasi, solidaritas, dan hasil pembinaan (Hezberg, 1996 dalam Wahjosumidjo, 2000).

Teknik analisis dalam penelitian ini dilakukan dengan cara mendeskripsikan dan menginterpretasikan data untuk menggambarkan fenomena yang terjadi. Teknik analisis yang digunakan untuk mengukur keeratan hubungan kedua variabel adalah korelasi Rank Spearman. Keeratan hubungan kedua variabel kemudian diinterpretasikan ke dalam aturan Guilford (1956) dalam Rakhmat (1998).

\section{HASIL DAN PEMBAHASAN}

\section{a. Motivasi Peternak Perempuan}

Motivasi merupakan kegiatan yang mendorong, meningkatkan gairah, mengajak seseorang untuk bekerja agar lebih efektif, dan 
meninggalkan praktik-praktik yang tidak produktif, serta merupakan bagian pokok dari usaha meningkatkan keuangan (Kusriyanto, 1991). Motivasi peternak perempuan berupa timbulnya suatu keinginan dari dalam diri dan dari faktor lingkungan guna memenuhi kebutuhan hidupnya. Motivasi peternak perempuan dapat dilihat pada Tabel 2 .

Tabel 2. Motivasi Peternak Perempuan

\begin{tabular}{|c|c|c|c|c|}
\hline \multirow{2}{*}{$\begin{array}{l}\mathrm{N} \\
\mathrm{o}\end{array}$} & \multirow{2}{*}{ Uraian } & \multicolumn{3}{|c|}{ Kategori (\%) } \\
\hline & & Tinggi & Sedang & Rendah \\
\hline 1 & $\begin{array}{l}\text { Motivasi } \\
\text { Intrinsik }\end{array}$ & 40,00 & 50,00 & 10,00 \\
\hline 2 & $\begin{array}{l}\text { Motivasi } \\
\text { Ekstrinsik }\end{array}$ & 50,00 & 46,67 & 3,33 \\
\hline & $\begin{array}{l}\text { Rekapitul } \\
\text { asi } \\
\text { Motivasi }\end{array}$ & 36,67 & 60,00 & $\mathbf{3 , 3 3}$ \\
\hline
\end{tabular}

Motivasi intrinsik peternak perempuan pada penelitian ini termasuk dalam kategori sedang (50\%). Motivasi untuk bertanggung jawab pada peternak perempuan dalam melaksanakan pekerjaannya cukup baik. Tanggung jawab merupakan kesadaran seseorang akan tingkah laku atau perbuatan, baik disengaja maupun tidak. Tanggung jawab juga merupakan perwujudan kesadaran atas kewajibannya. Tanggung jawab seorang perempuan terutama yang sudah berkeluarga adalah mengurus keluarganya seperti mengurus suami, anak, dan pekerjaan rumahnya serta pekerjaan lainnya jika mereka memiliki pekerjaan lain selain pekerjaan rumah tangga. Peternak perempuan di Kelurahan Cipari bersedia bekerja dengan keseriusan agar usaha peternakan sapi perahnya tetap bertahan dan dapat memenuhi kebutuhan hidupnya. Hal ini dibuktikan dari kegiatan-kegiatan peternak perempuan tersebut dalam mengurus ternak sapi perahnya seperti membersihkan ternak, membersihkan kandang, memerah, dan memberi pakan. Rata-rata kegiatan tersebut dilakukan dua kali dalam sehari serta dilakukan sendiri apabila suami bekerja dan anak sekolah.
Sebagian besar peternak perempuan di Kelurahan Cipari mempunyai motivasi yang baik dalam menginginkan kesempatan maju guna meningkatkan kualitas hidup. Kesempatan maju yang didapat dengan bergabung sebagai anggota KSU Karya Nugraha ialah fasilitas produksi ternak yang disediakan koperasi untuk anggotanya, dan sistem pembayaran "gajian potong" menurut istilah setempat. Fasilitas ini memungkinkan peternak perempuan hanya perlu mengambil apa yang mereka perlukan terlebih dahulu untuk usaha ternak sapi perahnya, lalu untuk pembayarannya akan dikalkulasikan oleh pihak KSU dan dipotong saat hari pembagian gaji. Tentunya hal tersebut memudahkan peternak perempuan dalam beternak sapi perah.

Tingginya keinginan untuk meraih kesempatan maju dalam usaha ternak sapi perahnya tidak terlepas dari suatu kondisi yang mendesak atas kebutuhan hidupnya. Kebutuhan yang dimaksud yaitu menabung agar dapat digunakan ketika membutuhkan, membiayai pendidikan anak-anaknya karena sudah pasti seorang ibu ingin kebutuhan pendidikan anaknya tercukupi, serta kebutuhkan keluarga yang masih kurang apabila hanya mengandalkan pendapatan suami. Oleh karena itu, mereka termotivasi untuk serius dalam menjalankan usaha ternaknya. Hal tersebut selaras dengan pernyataan Nawawi (2001), bahwa pendorong kerja yang bersumber dari diri pekerja sebagai individu berupa suatu kondisi yang mengharuskannya melaksanakan pekerjaan secara maksimal.

Motivasi ekstrinsik merupakan motivasi yang berasal dari luar diri seseorang atau dari lingkungan. Motivasi dari luar merupakan motivasi yang muncul sebagai akibat adanya pengaruh yang ada di luar pekerjaan atau dari luar diri pekerja itu sendiri. Motivasi ekstrinsik peternak perempuan pada penelitian ini berada pada kategori tinggi (50\%). Bergabung dengan koperasi berarti bergabung juga dengan salah satu kelompok peternak sapi perah di Kelurahan 
Cipari. Sebagian besar responden menilai dengan bergabung ke dalam kelompok ternak sapi perah, sehingga relasi yang mereka peroleh dalam kelompok memberikan manfaat pada usaha peternakan sapi perahnya. Relasi yang dilakukan antar sesama anggota peternak sapi perah memberi manfaat dalam hal berbagi informasi mengenai cara mendapatkan kualitas susu yang baik, pengolahan susu, serta informasi mengenai pakan untuk sapi perah. Hal ini sangat memberikan manfaat bagi peternak perempuan tersebut karena biasanya pada awal memulai usaha peternakan sapi perah, peternak perempuan tidak terlalu mengetahui manajemen yang baik dalam beternak sapi perah dan juga biasanya relasi peternak perempuan tidak sebanyak relasi peternak laki-laki.

Solidaritas merupakan suatu sikap yang dimiliki oleh manusia dalam kaitannya dengan ungkapan perasaan manusia atas rasa senasib dan sepenanggungan terhadap orang lain maupun kelompok. Solidaritas dalam penelitian ini menunjuk kepada bagaimana peternak perempuan saling berbagi dan saling meringankan beban baik dengan sesama anggota peternak perempuan maupun dengan anggota peternak lainnya. Berdasarkan hasil penelitian, dapat dilihat bahwa solidaritas peternak perempuan baik. Peternak perempuan sadar bahwa dalam menjalani usaha ternak sapi perah pasti menghadapi beberapa kendala, oleh karena itu mereka termotivasi untuk membantu satu sama lain. Hal ini terbukti oleh bagaimana peternak perempuan tersebut membantu antar sesama peternak lainnya, seperti meminjamkan pakan ketika ada peternak yang sedang kekurangan stok pakan, membantu memberi pakan pada peternak yang meminta bantuan karena mempunyai kepentingan lain yang tidak bisa ditinggalkan, serta terkadang membantu saat ada sapi peternak yang melahirkan.

Berdasarkan hasil penelitian, responden menyatakan bahwa pembinaan melalui penyuluhan dibutuhkan untuk menambah wawasan dalam beternak sapi perah.
Berdasarkan karakteristik lama beternak, responden peternak perempuan di Kelurahan Cipari mempunyai pengalaman beternak yang cukup lama, namun masih membutuhkan pembinaan untuk menambah keterampilan kerja beternak sapi perah. Hal ini karena penyuluhan untuk peternak sapi perah di Kelurahan Cipari dilakukan dengan sistem undangan. Hanya anggota yang mendapat undangan yang dapat menghadiri. Undangan tersebut lebih sering didapatkan oleh peternak laki-laki sehingga peternak perempuan yang tidak mendapat undangan biasanya mencari tahu informasi hasil kegiatan penyuluhan kepada peternak yang mendapat undangan.

Hal ini menunjukan bahwa masih adanya ketidakseimbangan pemberdayaan dalam masyarakat antara kaum laki-laki dan perempuan. Perempuan sejatinya perlu diberdayakan karena perempuan memiliki kepentingan yang sama dalam pembangunan yang juga merupakan pengguna hasil pembangunan yang memiliki hak yang sama dengan laki-laki (Ratnawati, 2012).

\section{b. Keberlanjutan Usaha}

Keberlanjutan usaha merupakan terjemahan dari "Sustainable Livelihood" dapat didefinisikan sebagai upaya seseorang atau sekelompok orang untuk memenuhi kebutuhan hidup dan keberlanjutan hidupnya dengan memanfaatkan segala kemampuan, pengetahuan, akses, dan tuntutan serta kekayaan yang dimiliki, serta terus meningkatkan kemampuan dirinya dengan bekerja sama dengan orang lain, berinovasi, berkompetisi agar dapat bertahan dalam berbagai perubahan dan tercapainya suatu kecukupan dan keadlian (Chambers dan Conway, 1992 dalam Nurlina, 2008).

Berdasarkan Tabel 3 terlihat bahwa keberlanjutan usaha peternak perempuan dalam penelitian ini termasuk ke dalam kategori sedang $(53,33 \%)$. Variabel keberlanjutan usaha 
dilihat dari tiga sub-variabel yaitu kemampuan (capabilities), keadilan berusaha (equity), dan kemandirian (Sustainability). Kemampuan (capabilities) pada peternak perempuan termasuk ke dalam kategori sedang $(63,33 \%)$ menunjukan bahwa kemampuan peternak perempuan dalam beternak sapi perah tidak terlalu rendah maupun terlalu tinggi. Faktor kemampuan terbagi atas lima indikator, yaitu (1) perencanaan usaha, (2) adaptasi resiko usaha, (3) inovatif, (4) kerjasama, dan (5) evaluasi. Keadilan berusaha (equity) dari peternak perempuan termasuk ke dalam kategori tinggi $(70 \%)$ dan untuk kemandirian (sustainability) termasuk ke dalam kategori rendah $(60 \%)$. Faktor keadilan berusaha terbagi atas indikator (1) persepsi terhadap keuntungan usaha dan (2) pengembangan investasi dan untuk faktor kemandirian terdiri atas indikator (1) pemanfaatan sumber daya manusia.

Tabel 3. Keberlanjutan Usaha Peternak Perempuan

\begin{tabular}{lllll}
\hline \multirow{2}{*}{ No } & \multirow{2}{*}{ Uraian } & \multicolumn{3}{c}{ Kategori (\%) } \\
\cline { 3 - 5 } & & Tinggi & Sedang & Rendah \\
\hline 1 & Capabilities & 23,33 & 63,33 & 13,33 \\
2 & Equity & 70,00 & 10,00 & 20,00 \\
3 & Sustainability & 13,33 & 26,67 & 60,00 \\
\hline \multirow{3}{*}{} & Rekapitulasi & & & \\
& Keberlanjutan & 30,00 & 53,33 & 16,67 \\
& Usaha & & & \\
\hline
\end{tabular}

Konsep kemampuan (capabilities) yang sering diartikan sebagai kemampuan untuk bertahan dalam menghadapi stress dan shock, mampu menemukan dan memanfaatkan kesempatan dalam kehidupan ekonomi. Tidak hanya kemampuan reaktif tapi juga kemampuan proaktif, mampu merespon terhadap perubahan serta dapat beradaptasi dengan dinamis (Nurlina, 2008). Perencanaan usaha yang dilakukan peternak perempuan di Kelurahan Cipari sebagian belum maksimal dalam kenyataannya. Hasil penelitian menunjukan bahwa perencanaan usaha yang biasa dilakukan peternak perempuan di Kelurahan Cipari lebih mengarah kepada cara meningkatkan populasi melalui replacement stock, memperluas lahan, serta meningkatkan jumlah susu. Peternak perempuan tidak ada sama sekali melakukan perencanaan usaha yang kompleks seperti studi kelayakan, bahkan untuk perencanaan sederhana secara tertulis pun hanya sedikit yang melakukan. Hal tersebut karena masih kurangnya pengetahuan peternak perempuan terhadap bagaimana perencanaan usaha yang baik, serta masih belum maksimalnya pembinaan bagi peternak perempuan. Umumnya mereka sudah melakukan sebuah perencanaan usaha, akan tetapi hanya sebatas pemikiran sesaat atau berencana pada jangka waktu yang tidak panjang.

Menjalankan usaha peternakan sapi perah tentunya tidak terlepas dari kendala-kendala yang merupakan resiko dari usahanya. Maka dari itu, peternak dituntut agar dapat menyesuaikan diri atau beradaptasi dengan resiko tersebut. Adaptasi resiko usaha merupakan suatu upaya peternak perempuan di Kelurahan Cipari untuk dapat menyesuaikan diri dan tanggap dalam merespon masalah pada usaha yang dijalankan. Masalah yang dihadapi yaitu kekurangan modal atau biaya, ternak sakit, kematian ternak, serta penurunan kualitas dan jumlah susu. Akan tetapi kemampuan responden dalam adaptasi resiko usaha sudah bisa dikatakan cukup baik, hal ini dapat dilihat dari bagaimana responden masih tetap bertahan dalam menjalankan usahanya meski sudah menemui berbagai masalah.

Bergabung dengan kelompok tentunya menghasilkan sebuah relasi yang menimbulkan adanya kerjasama antar anggotanya. Kerjasama yang dilakukan peternak perempuan Kelurahan Cipari biasanya berupa membersihkan kandang bersama dan mencari rumput bersama. Kerjasama tersebut terjadi karena rata-rata kandang mereka menempel. Peternak perempuan merasa diuntungkan dengan bergabung dengan kelompok karena bisa mendapatkan teman untuk bekerjasama seperti 
mencari rumput bersama. Menurut Soekanto (2007), kerjasama adalah suatu usaha bersama antara orang-perorangan atau kelompok manusia guna mencapai suatu tujuan bersama.

Melakukan evaluasi dalam suatu usaha berguna untuk mengetahui bagaimana kentungan atau kerugian dari usahanya, serta dapat pula mencegah kerugian. Menurut Nurkancana (1983), evaluasi adalah kegiatan yang dilakukan berkenaan dengan proses untuk menentukan nilai dari suatu hal. Sebagian besar evaluasi yang dilakukan peternak perempuan Kelurahan Cipari berupa memberikan tambahan pakan guna meningkatkan jumlah produksi susu dan memeriksa kesehatan ternaknya dari nafsu makan, kulit, dan hidung. Apabila nafsu makan ternak menurun biasanya responden melakukan pemberian air gula terlebih dahulu sebelum melapor ke petugas kesehatan KSU untuk meningkatkan nafsu makan ternaknya kembali. Namun, apabila dirasa tidak memberikan perubahan mereka langsung melapor kepada petugas kesehatan KSU. Evaluasi perhitungan biaya secara tertulis masih jarang dilakukan peternak, mereka mengatakan selama hasil keuntungan bisa diputar tidak perlu dilakukan evaluasi biaya. Dilihat dari hasil penelitian, responden sebenarnya dapat dikatakan sudah menyadari pentingnya sebuah evalusi karena evaluasi merupakan bagian penting dalam suatu usaha guna mencegah kerugian.

Konsep keadilan berusaha (equity) atau disebut juga sebagai keadilan konvensional yang dapat diukur dari distribusi dan pendapatan relatif. Konsep equity lebih luas menunjuk kepada bagaimana pendistribusian aset (kekayaan), kemampuan dan kesempatan, terkhusus pada perempuan, golongan minoritas, mereka yang lemah dan miskin di kota maupun desa (Nurlina, 2008).

Responden mengatakan bahwa usaha sapi perah yang dijalankannya sudah cukup menguntungkan. Hal ini ditandai dengan masih bertahannya peternak perempuan dalam menjalankan usahanya. Meskipun tidak terlalu besar, seringkali peternak perempuan mendapat penerimaan lebih yang dapat disisihkan. Keuntungan tersebut mereka dapatkan dari penjualan susu, serta penjualan sapi nonproduktif seperti pedet dan jantan. Peternak perempuan menilai bahwa dengan beternak sapi perah dapat memenuhi kebutuhan pokok mereka dan dapat menambah penghasilan keluarga. Apabila mendapat penerimaan yang dapat disisihkan biasanya digunakan untuk memenuhi kebutuhan anaknya atau membayar tagihan (seperti tagihan kredit atau kredit KSU apabila mempunyai tunggakan). Hal ini juga tidak terlepas dari peran KSU Karya Nugraha sebagai penyedia fasilitas-fasilitas yang dapat membantu anggotanya dalam menjalankan usaha peternakan sapi perah.

Pengembangan investasi berkaitan dengan kemampuan peternak dalam mengelola usaha yang dijalankan. Penghasilan yang disisihkan selain digunakan untuk memenuhi kebutuhan anak atau membayar tagihan, ada pula peternak perempuan yang mengguna-kannya untuk perbaikan kandang, memperbaiki rumah, membeli isi rumah, atau membeli perhiasan. Mempunyai kandang milik sendiri juga merupakan sebuah tanda bahwa peternak perempuan sudah melakukan pengembangan investasi, karena ada yang kandang ternaknya masih mengontrak. Pengelolaan yang dilakukan peternak perempuan biasanya dilakukan dengan berdiskusi terlebih dahulu dengan keluarga terutama dengan suami sebagai kepala keluarga, karena meskipun suami bekerja di tempat lain mereka tetap membantu istrinya dalam pengelolaan usaha ternak sapiperahnya.

Konsep kemandirian (sustainability) merupakan terjemahan dari keberlanjut-an dapat dikonotasikan pada pemenuhan sendiri, pengendalian diri, dan percaya diri. Dilihat dari aspek sosial dalam konteks livelihood, keberlanjutan menunjuk kepada cara dan kemampuan memelihara dan mempertahankan mata pencahariannya (Nurlina, 2008). Hasil yang didapat menunjukan bahwa sebagian besar 
peternak perempuan Kelurahan Cipari telah melakukan pemanfaatan sumber daya manusia. Sumber daya manusia yang didayagunakan berasal dari keluarga seperti suami, anak, saudara, maupun orang lain seperti tetangga. Mereka dipekerjakan untuk membantu mengurus peternakan sapi perah setiap harinya. Namun, sebagian besar peternak perempuan hanya menggunakan keluarga sendiri, dengan alasannya karena tidak perlu mengeluarkan biaya tambahan untuk membayar, belum mampu membayar orang lain, serta kurangnya kepercayaan kepada orang lain. Kurangnya kepercayaan kepada orang lain diakibatkan oleh pengalamannya ketika mempekerjakan orang lain malah mengasilkan kerugian.

Tabel 4. Peningkatan Skala Pemilikan Berdasarkan Ternak Produktif

\begin{tabular}{ccccc}
\hline \multirow{2}{*}{$\begin{array}{c}\text { No Klasifikasi } \\
\text { Kepemilikan } \\
\text { (ekor) }\end{array}$} & \multicolumn{2}{c}{$\begin{array}{c}\text { Jumlah } \\
\text { Awal }\end{array}$} & \multicolumn{2}{c}{$\begin{array}{c}\text { Jumlah } \\
\text { Saat ini }\end{array}$} \\
\cline { 2 - 5 } & Orang & \multicolumn{1}{c}{ Orang } & $\%$ \\
\hline $1 \begin{array}{l}\text { Skala Kecil } \\
(1-3 \text { ekor) }\end{array}$ & 30 & 100,00 & 17 & 56,67 \\
$2 \begin{array}{c}\text { Skala } \\
\begin{array}{l}\text { Menengah (4- } \\
7 \text { ekor) }\end{array}\end{array}$ & 0 & 0,00 & & \\
$3 \begin{array}{l}\text { Skala Besar } \\
\text { (>7 ekor) }\end{array}$ & 0 & 0,00 & 2 & 6,67 \\
\hline Jumlah Total & 30 & 100,00 & 30 & 100,00 \\
\hline
\end{tabular}

Berdasarkan Tabel 4 terlihat bahwa seluruh skala pemilikan ternak responden termasuk ke dalam skala kecil. Hal ini karena pada awalnya responden hanya memiliki 1-3 ekor ternak produktif saja atau hanya memiliki pedet betina. Apabila dilihat jumlah saat ini, kenaikan skala pemilikan ternak produktif responden tidak terlalu besar. Hal ini disebabkan beberapa alasan, seperti ternak yang sakit, mati, dijual, atau sudah merasa usahanya cukup menguntungkan dengan jumlah ternak yang ada. Meskipun kenaikannya tidak begitu besar, namun tetap dapat dikatakan bahwa peternak perempuan tersebut sudah bisa memelihara dan mempertahankan usahanya.

\section{a. Hubungan Motivasi Peternak Perempuan dengan Keberlanjutan Usaha Peternakan Sapi Perah}

Berdasarkan hasil perhitungan korelasi rank spearman $\left(\mathrm{r}_{\mathrm{s}}\right)$ dengan menggunakan aplikasi SPSS, diperoleh signifikasi sebesar 0,004 dengan $\alpha$ sebesar 0,05 . Nilai signifikasi $<0,05$ maka dapat disimpulkan bahwa $\mathrm{H}_{1}$ diterima atau terdapat hubungan positif antara motivasi peternak perempuan dengan keberlanjutan usaha. Nilai koefisien korelasi diperoleh sebesar 0,472 antara motivasi (X) dengan keberlanjutan usaha (Y). Mengacu pada aturan Guilford, dengan nilai koefisien 0,472 dapat disimpulkan bahwa hubungan antara motivasi peternak perempuan dengan keberlanjutan usaha termasuk hubungan yang cukup kuat. Hasil perhitungan SPSS dapat dilihat pada Tabel 5.

Hubungan yang cukup kuat menyatakan bahwa motivasi dari peternak perempuan merupakan salah satu faktor yang dapat menentukan keberlanjutan usaha. Hal ini terilihat dari motivasi peternak perempuan di Kelurahan Cipari yang sudah cukup baik, baik dari motivasi intrinsik maupun motivasi ekstrinsik. Peternak perempuan sudah sadar akan tanggung jawab atas kewajibankewajibannya dalam menjalankan usaha peternakan sapi perah, dan juga melakukan kegiatan beternak sapi perahnya karena sadar akan adanya kesempatan maju yang diperoleh dari usahanya. Selain termotivasi dari dalam diri, peternak perempuan di Kelurahan Cipari juga didorong oleh faktor luar seperti dengan mendapatkan relasi setelah bergabung dengan kelompok ternak sapi perah, dimana dengan mendapat relasi mereka bisa memperoleh informasi-informasi yang menunjang kegiatan usaha ternak sapi perahnya. Solidaritas yang timbul dari sesama anggota juga menjadi dorongan bagi peternak perempuan menjalankan usaha ternaknya. Peternak perempuan juga termotivasi dengan adanya pembinaan yang diberikan di setiap 
kelompoknya meskipun kesempatan memperoleh pembinaan peternak perempuan lebih sedikit dibanding peternak laki-laki.

Tabel 5. Korelasi Hubungan Variabel $X$ dan Variabel Y

\begin{tabular}{lrrr|r}
\hline $\begin{array}{l}\text { Spearman's } \\
\text { rho }\end{array}$ & XTOT & $\begin{array}{l}\text { Correlation } \\
\text { Coefficient }\end{array}$ & 1,000 &, $472^{* *}$ \\
\cline { 3 - 4 } & & $\begin{array}{r}\text { Sig.(1- } \\
\text { tailed) }\end{array}$ &, 004 \\
\cline { 2 - 4 } & $\mathrm{N}$ & 30 & 30 \\
\cline { 2 - 4 } & YTOT & $\begin{array}{r}\text { Correlation } \\
\text { Coefficient }\end{array}$ &, $472^{* *}$ & 1,000 \\
\cline { 2 - 4 } & $\begin{array}{r}\text { Sig.(1- } \\
\text { tailed) }\end{array}$ &, 004 & \\
\hline & $\mathrm{N}$ & 30 & 30 \\
\hline
\end{tabular}

Keberlanjutan usaha yang dijalankan peternak perempuan di Kelurahan Cipari berdasarkan hasil yang diperoleh sudah cukup baik. Dilihat dari kemampuan (capabilities) peternak perempuan sebagai manajer, sudah mampu memutuskan apa yang harus dilakukan dalam menjalankan usaha ternak sapi perahnya dan juga dapat beradaptasi dengan berbagai masalah yang timbul. Peternak perempuan sudah merasakan keadilan berusaha (equity) dari usahanya. Namun, perlu adanya peningkatan pada indikator kemandirian (sustainability) agar lebih maksimal.

Hubungan yang positif antara motivasi peternak perempuan dengan keberlanjutan usaha menandakan bahwa hubungannya searah. Artinya, apabila motivasinya semakin ditingkatkan maka keberlanjutan usaha juga akan meningkat. Pada dasarnya adanya motivasi dan kebelanjutan usaha adalah untuk memenuhi kebutuhan hidup agar bisa bertahan hidup. Apabila usaha yang dilakukan dapat bertahan maka pemenuhan kebutuhan hidup akan terjamin. Hal ini selaras dengan pendapat Ashari (2010), bahwa motivasi mempertahankan keberlanjutan usaha adalah keinginan yang berimplikasi terhadap berlanjutnya suatu usaha dan secara garis besar terhindar dari suatu kebangkrutan.

\section{KESIMPULAN}

\section{a. Kesimpulan}

Berdasarkan hasil penelitian dan pembahasan, maka dapat ditarik kesimpulan sebagai berikut:

1. Motivasi peternak perempuan anggota KSU Karya Nugraha di Kelurahan Cipari berdasarkan hasil penelitian termasuk pada kategori sedang $(60 \%)$ yang artinya sudah cukup baik namun masih perlu untuk lebih dimaksimalkan.

2. Keberlanjutan usaha peternak perempuan anggota KSU Karya Nugraha di Kelurahan Cipari berdasarkan hasil penelitian termasuk pada kategori sedang $(53,33 \%)$ yang artinya sudah cukup baik dalam memelihara dan mempertahankan usahanya namun masih perlu untuk lebih dimaksimalkan.

3. Terdapat hubungan positif dan cukup kuat antara motivasi peternak perempuan di Kelurahan Cipari dengan keberlanjutan usaha yang dijalankannya dengan koefisien korelasi sebesar 0,472 .

\section{DAFTAR PUSTAKA}

Arep dan Tanjung. 2003. Manajemen Motivasi. Grasindo. Jakarta.

Ashari, 2010. Manajemen Mutu Sumber Daya Manusia. Ghalia Indonesia. Bogor.

Direktorat Jenderal Peternakan dan Kesehatan Hewan 2018. Statistik peternakan dan Kesehatan Hewan 2018. Kementrian Pertanian Republik Indonesia. Jakarta.

Kusriyanto, B. 1991. Manajemen Sumber Daya Manusia. Bumi Aksara. Jakarta.

Nawawi, H.H. 2001. Manajemen Sumber Daya Manusia. Gadjah Mada University Press. Yogyakarta.

Nurkancana, W. 1983. Evaluasi Pendidikan. Usaha Nasional. Surabaya.

Nurlina, L. 2008. Peranan Kepemimpinan Penyuluh Peternakan Dalam Upaya Mempertahankan Keberlanjutan Usaha 
Anggota Koperasi ( Kasus Di Koperasi Unit Desa Sapi Perah Cipta Sari Kecamatan Anjasari Kabupaten Bandung). Disertasi. Fakultas Peternakan Universitas Padjajaran. Sumedang.

Rakhmat, J. 1998. Metode Penelitian. PT. Remaja Rosdakarya. Bandung.

Ratnawati, I. 2012. Pengaruh Budaya Organisasi dan Kepuasan Kerja terhadap Kinerja Karyawan (Studi pada Rumah Sakit Panti
Wilasa "Citarum" Kota Semarang). Jurnal Manajemen Diponegoro Volume 1.

Reksohadiprodjo, S. 1995. Pengantar Ilmu Peternakan Tropik. Edisi kedua. BPFE. Yogyakarta

Soekanto, S. 2007. Sosiologi Suatu Pengantar. PT. Raja Grafindo. Jakarta.

Wahjosumidjo. 2000. Kepemimpinan dan Motivasi. Chaila. Jakarta. 